\title{
Co-ordination Chemistry of Dimethylgold(III). Synthesis, Spectroscopic, and Structural Studies* of Complexes with Neutral Aromatic Nitrogen-donor Ligands
}

\author{
Allan J. Canty and Nigel J. Minchin \\ Chemistry Department, University of Tasmania, Hobart, Tasmania, Australia 7001 \\ Peter C. Healy \\ School of Science, Griffith University, Nathan, Queens/and, Australia 4111 \\ Allan H. White \\ Department of Physical and Inorganic Chemistry, University of Western Australia, Nedlands, W.A. 6009
}

\begin{abstract}
Dimethylgold(III) nitrate reacts with neutral ligands to form the complexes [AuMe $(\operatorname{tpm})] \mathrm{NO}_{3} \cdot 2 \mathrm{H}_{2} \mathrm{O}$ $\left(\mathrm{tpm}=\right.$ tri-2-pyridylmethane) and $\left[\mathrm{AuMe}_{2} \mathrm{~L}\right] \mathrm{NO}_{3}[\mathrm{~L}=$ tri-2-pyridylmethanol (tpmo), di-2-pyridylmethane (dpm), $\alpha \alpha$-di-2-pyridyltoluene (dpt), di-1-pyrazolylmethane (dpzm), and tri-1-pyrazolylmethane (tpzm) ]. The crystal structures of complexes of tpzm, tpm, and dpt have been determined by single-crystal $X$-ray diffraction at $295 \mathrm{~K}$ and refined by least-squares methods to $R=0.033,0.029$, and 0.042 for 3043,1616 , and 2529 independent 'observed ' reflections, respectively. In these structures the $\left[\mathrm{AuMe}_{2} \mathrm{~L}\right]^{+}$cations have essentially cis-square-planar co-ordination for gold(III), $\mathrm{AuC}_{2} \mathrm{~N}_{2}$, with $\mathrm{Au}-\mathrm{C} 2.023(7)-2.041(12) \AA$ and $\mathrm{Au}-\mathrm{N}$ $2.127(8)-2.142(8) \AA$. In complexes of the potential tridentate ligands one pyridyl group is not co-ordinated in the tpm complex, and one pyrazolyl group is involved in a weak axial Au $\cdots \mathrm{N}$ interaction $[3.139(7) \AA]$ in the tpzm complex. Comparison of the ${ }^{1} \mathrm{H}$ n.m.r. spectra of complexes of the potentially tridentate ligands (tpzm, tpm, and tpmo) with model complexes of bidentate ligands (dpzm, dpm, and dpt) suggests that the co-ordination behaviour of the ligands in methanol resembles that found in the solid state. Crystal data: $\left[\mathrm{AuMe} \mathrm{M}_{2}(\mathrm{tpzm})\right] \mathrm{NO}_{3}$, monoclinic, space group $P 2_{1} / n$, $a=16.72(1), b=9.662(3), c=10.700(4) \AA, \beta=107.83(3)^{\circ}, Z=4 ;\left[\mathrm{AuMe}_{2}(\mathrm{tpm})\right] \mathrm{NO}_{3} \cdot 2 \mathrm{H}_{2} \mathrm{O}$, orthorhombic, space group $P 2{ }_{1} 2_{1} 2_{1}, a=18.56(1), b=11.150(7), c=9.983(7) \AA, Z=4$; $\left[\mathrm{AuMe}_{2}(\mathrm{dpt}) \mathrm{NO}_{3}\right.$, monoclinic, $P 21 / n, a=14.142(6), b=13.012(7), c=10.372(3) \AA$, $\beta=100.60(3)^{\circ}, Z=4$.
\end{abstract}

Reaction of the organometallic cations $\left[\mathrm{Hg}^{11} \mathrm{Me}\right]^{+}$and $\left[\mathrm{Au}^{\mathrm{III}} \mathrm{Me}_{2}\right]^{+}$with unidentate ligands commonly leads to the formation of complexes with linear ${ }^{1}$ and square-planar ${ }^{2,3}$ co-ordination geometries respectively. However, in the presence of some polydentate nitrogen-donor ligands (L), four-co-ordinate stereochemistry has been observed for $\mathbf{H g}^{\mathbf{1 1}}$ in complexes of the type $[\mathrm{MeHgL}] \mathrm{NO}_{3},{ }^{4}$ and five-co-ordinate intermediates $\left[\mathrm{AuMe}_{2} \mathrm{~L}\right]^{+}$have been proposed in exchange processes. ${ }^{5,6}$ In particular, the tridentate tripod ligand tri-2-

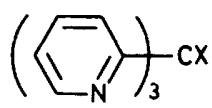

$X=H(t p m)$

$X=O H(t p m o)$

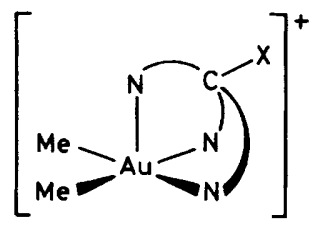

(A)



tpzm

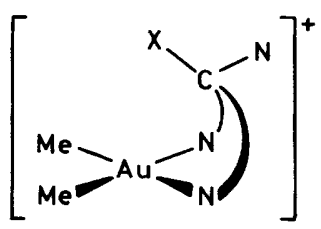

(B)

\footnotetext{
* Supplementary data available (No. SUP 23336; 39 pp.): thermal parameters, hydrogen atom geometries, ligand plane data, observed and calculated structure factors. See Notices to Authors No. 7, J. Chem. Soc., Dalton Trans., 1981, Index issue.
}

pyridylmethanol (tpmo) binds as a tridentate ligand to $\mathrm{HgMe}^{4}$ and thus this ligand, and similar ones such as tri-1-pyrazolylmethane (tpzm), may encourage five-co-ordination for gold with $\mathrm{AuMe}_{2}$ [structure (A)]; alternatively, these ligands are not rigid and thus may allow the gold atom to adopt the common square-planar geometry with the ligand adopting a bidentate configuration as in (B).

We report in this paper a study of the structural chemistry and spectroscopic properties of $\left[\mathrm{Au}^{\mathrm{III}} \mathrm{Me}_{2}\right]^{+}$with the potentially tridentate ligands tpm, tpmo, and tpzm, and the related bidentate ligands di-2-pyridylmethane (dpm), $\alpha \alpha$-di-2-pyridyltoluene $(\mathrm{dpt})$, and di-1-pyrazolylmethane (dpzm).

\section{Experimental}

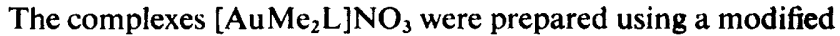
method of that reported for the closely related complex $\left[\right.$ AuEt ${ }_{2}$ (bipy) $\mathrm{NO}_{3}$ (bipy $=2,2^{\prime}$-bipyridyl), ${ }^{7}$ and similar to that used by Tobias and co-workers for interconversion of $\mathrm{AuMe}_{2}$ halides ${ }^{8}$ and synthesis of $\mathrm{AuMe}_{2}$ amino-acidato-complexes. ${ }^{9}$

The ligands dpzm and tpzm were used as received (Columbia Organic Chemicals Company, Inc.); the ligands dpm, ${ }^{10}$ $\mathrm{tpm},{ }^{11}$ and $\mathrm{dpt}^{4}$ were prepared as described, and dimethylgold(III) iodide was prepared from $\left[\mathrm{AuCl}_{3}(\mathrm{py})\right]$ (py = pyridine) as previously described..$^{12}$ Microanalyses were by the Australian Microanalytical Service, i.r. spectra $\left(400-4000 \mathrm{~cm}^{-1}\right)$ of complexes in Nujol and hexachlorobutadiene mulls were recorded with a Perkin-Elmer 577 spectrophotometer, ${ }^{1} \mathrm{H}$ n.m.r. spectra were recorded with a JEOL JNM-4H-100 spectrometer, and Raman spectra of crystalline solids were recorded with a Cary 82 laser Raman spectrometer over the range $100-4000 \mathrm{~cm}^{-1}$ using $514.5 \mathrm{~nm}$ excitation. Some of the complexes decomposed using this wavelength and these were 
Table 1. Analytical and spectroscopic data

\begin{tabular}{|c|c|c|c|c|c|c|c|}
\hline \multirow[t]{2}{*}{ Complex } & \multirow{2}{*}{$\begin{array}{c}\text { M.p. } \\
\text { (decomp.) } \\
\left(\theta_{c} /{ }^{\circ} \mathrm{C}\right)\end{array}$} & \multicolumn{3}{|c|}{ Analysis $(\%)^{a}$} & \multirow{2}{*}{$\begin{array}{c}\Lambda_{\mathrm{M}}{ }^{\mathrm{b}} ! \\
\Omega^{-1} \mathrm{~cm}^{2} \mathrm{~mol}^{-1}\end{array}$} & \multirow[b]{2}{*}{$v\left(\mathrm{AuC}_{2}\right)^{c} / \mathrm{cm}^{-1}$} & \multirow[b]{2}{*}{${ }^{1} \mathrm{H}$ n.m.r. ${ }^{d}$} \\
\hline & & $\mathrm{C}$ & $\mathrm{H}$ & $\mathbf{N}$ & & & \\
\hline$\left[\mathrm{AuMe}_{2}(\mathrm{dpm}) \mathrm{NOO}_{3}\right.$ & 193 & $\begin{array}{c}35.0 \\
(34.9)\end{array}$ & $\begin{array}{c}3.6 \\
(3.6)\end{array}$ & $\begin{array}{l}9.1 \\
(9.4)\end{array}$ & 89 & 583,576 & $\begin{array}{l}1.46,6, s, \mathrm{Me} ; 4.69,2, s, \mathrm{CH}_{2} \\
7.90,6, m, \mathrm{H}(3,4,5) ; 8.73 \\
2, d, \mathrm{H}(6)\end{array}$ \\
\hline$\left[\mathrm{AuMe}_{2}(\mathrm{dpt})\right] \mathrm{NO}_{3}$ & 174 & $\begin{array}{l}42.5 \\
(42.6)\end{array}$ & $\begin{array}{c}3.9 \\
(3.8)\end{array}$ & $\begin{array}{c}7.8 \\
(7.8)\end{array}$ & 86 & 581,569 & $\begin{array}{l}0.95,6, s, \mathrm{Me} ; 6.26,1, s, \mathrm{CH} ; \\
6.68,2, m\{\mathrm{Ph}[\mathrm{H}(2,6)]\} ; 7.32,3 \text {, } \\
m,\{\mathrm{Ph}[\mathrm{H}(3,4,5)]\} ; 7.80,2, t, \\
\mathrm{H}(4) ; 8.25,4, m, \mathrm{H}(3,5) ; \\
8.76,2, d \mathrm{H}(6)\end{array}$ \\
\hline$\left[\mathrm{AuMe}_{2}(\mathrm{tpm})\right] \mathrm{NO}_{3} \cdot 2 \mathrm{H}_{2} \mathrm{O}$ & $76-78$ & $\begin{array}{c}37.8 \\
(37.9)\end{array}$ & $\begin{array}{l}4.0 \\
(4.1)\end{array}$ & $\begin{array}{l}9.7 \\
(9.8)\end{array}$ & 98 & 585,574 & $\begin{array}{l}1.02,6, s, \mathrm{Me} ; 6.45,1, s, \mathrm{CH} \\
7.70,6, m, \mathrm{H}(3,5) ; 8.14,3, t \\
\mathrm{H}(4) ; 8.68,3, d, \mathrm{H}(6)\end{array}$ \\
\hline$\left[\mathrm{AuMe}_{2}(\mathrm{tpmo})\right] \mathrm{NO}_{3}$ & 115 & $\begin{array}{c}39.2 \\
(39.1)\end{array}$ & $\begin{array}{c}3.7 \\
(3.5)\end{array}$ & $\begin{array}{l}10.1 \\
(10.1)\end{array}$ & 96 & 584,572 & $\begin{array}{l}0.87,6, s, \mathrm{Me} ; 7.6,3, t, \mathrm{H}(4) \\
8.10,6, m, \mathrm{H}(3,5) ; 8.62,3, d, \\
\mathrm{H}(6)\end{array}$ \\
\hline$\left[\mathrm{AuMe}_{2}(\mathrm{dpzr})\right]_{\mathrm{NO}_{3}}$ & 127 & $\begin{array}{l}24.7 \\
(24.7)\end{array}$ & $\begin{array}{c}3.2 \\
(3.2)\end{array}$ & $\begin{array}{c}16.1 \\
(16.0)\end{array}$ & 91 & 582,576 & $\begin{array}{l}1.45,6, s, \mathrm{Me} ; 6.90,2, s, \mathrm{CH}_{2} \\
6.67,2, t, \mathrm{H}(4) ; 8.05 \text { and } 8.28 \\
4, d, \mathrm{H}(3,5)\end{array}$ \\
\hline$\left[\mathrm{AuMe}_{2}(\mathrm{tpzm})\right] \mathrm{NO}_{3}$ & 84 & $\begin{array}{r}28.6 \\
(28.6)\end{array}$ & $\begin{array}{c}3.3 \\
(3.2)\end{array}$ & $\begin{array}{r}19.4 \\
(19.5)\end{array}$ & 85 & 583 & $\begin{array}{l}1.34,6, s, \mathrm{Me} ; 9.60,1, s, \mathrm{CH} \\
6.60,3, t, \mathrm{H}(4) ; 8.06 \text { and } 8.27 \\
4, d, \mathrm{H}(3,5)\end{array}$ \\
\hline
\end{tabular}

${ }^{a}$ Calculated values are given in parentheses. ${ }^{b}$ In water. ${ }^{c}$ Raman spect
given as chemical shift, relative intensity, multiplicity, assignment.

satisfactorily re-examined with a Coherent Radiation dye laser Model 590 using Rhodamine 6G dye and with excitation in the range $580-590 \mathrm{~nm}$. Conductivities were measured with a Philips PW 9504/00 conductivity meter in water.

[AuCl$\left.{ }_{3}(\mathrm{py})\right]$.-As this compound is a convenient starting reagent for the synthesis of $\left(\mathrm{AuMe}_{2} \mathrm{I}\right)_{2},{ }^{12}$ the common method for recovery of gold from laboratory residues ${ }^{13}$ was modified to give this reagent directly. Gold residues were evaporated on a steam bath, concentrated hydrochloric acid was added, followed by evaporation to low volume on a steam bath, and slow heating to dryness on a hot plate. The solid material was fired to $800^{\circ} \mathrm{C}$ in a furnace for $6 \mathrm{~h}$, washed with warm water, and dissolved in aqua regia. The solution was reduced in volume to near dryness, concentrated hydrochloric acid added, and, while hot, the solution was filtered into a separating funnel. Auric acid $\left(\mathrm{HAuCl}_{4}\right)$ was extracted into ethyl acetate with continued addition of concentrated hydrochloric acid until the colour was discharged from the aqueous phase. The ethyl acetate solution was filtered and reduced in volume in a strong draught. Pyridine was added until crystallization of $\left[\mathrm{AuCl}_{3}(\mathrm{py})\right]$ ceased. The crystals were collected and washed with water.

Preparation of Complexes.-As all of the complexes were obtained in moderate yield $(28-82 \%)$ by similar procedures the preparation of $\left[\mathrm{AuMe}_{2}(\mathrm{dpzm}) \mathrm{NO}_{3}\right.$ is given as an example. Dimethylgold(III) iodide $(0.524 \mathrm{~g}, 0.74 \mathrm{mmol})$ suspended in light petroleum $\left(15 \mathrm{~cm}^{3}\right.$, b.p. $\left.40-60{ }^{\circ} \mathrm{C}\right)$ was added to a solution of silver nitrate $(0.250 \mathrm{~g}, 1.47 \mathrm{mmol})$ in water $\left(10 \mathrm{~cm}^{3}\right)$, and the solution stirred for $2 \mathrm{~h}$ in a flask covered with foil to exclude light. The light petroleum was removed by rotary evaporation and the insoluble silver iodide removed by filtration to give an aqueous solution of dimethylgold(III) nitrate. Di-1-pyrazolylmethane $(0.214 \mathrm{~g}, 1.45 \mathrm{mmol})$ was added with stirring until the ligand dissolved. On reduction of the volume in a strong draught, white crystals of the complex formed and were collected and recrystallized at room temperature from methanol-water $(1: 1)$ (yield $0.527 \mathrm{~g}, 82 \%$ ).
Crystallography.-For each complex a unique data set was measured at $295 \mathrm{~K}$ within a preset $2 \theta_{\max }$ limit determined by the extent of the data; Syntex $P I$ and $P 2_{1}$ four-circle diffractometers fitted with monochromatic Mo- $K_{\alpha}$ radiation sources $(\lambda=0.7106, \AA)$ were used in conventional $2 \theta-\theta$ scan mode, yielding $N$ independent reflections, $N_{0}$ of these with $I>$ $3 \sigma(I)$ being considered 'observed ' and used in the structure solution and refinement after the application of analytical absorption correction. Least-squares refinement was carried out using five blocks corresponding to the parameters of the $\mathrm{AuMe}_{2}$, nitrate, and ring fragments. Hydrogen atom parameters were constrained at idealized estimates. Anisotropic thermal parameters were used for the non-hydrogen atoms. Residuals quoted for convergence are conventional $R$ and $R^{\prime}$, reflection weights being set at $w=\left[\sigma^{2}\left(F_{0}\right)+0.0005\right.$ $\left.\left(F_{0}\right)^{2}\right]^{-1}$. Neutral-atom scattering factors corrected for anomalous dispersion $\left(f^{\prime}, f^{\prime \prime}\right)^{14-16}$ were employed. Computation used the X-RAY 76 program system ${ }^{17}$ implemented by $S$. R. Hall on a Perkin-Elmer 3240 computer. The results are given in Tables 2-6 and Figures 1-6.

Crystal data. $\left[\mathrm{AuMe}_{2}(\mathrm{tpzm})\right] \mathrm{NO}_{3}(1), \mathrm{C}_{12} \mathrm{H}_{16} \mathrm{AuN}_{7} \mathrm{O}_{3}, M=$ 502.9, Monoclinic, space group $P 2_{1} / n\left(C_{2 h}^{5}\right.$, no. 14), $a=$ 16.72(1), $b=9.662(3), c=10.700(4) \AA, \beta=107.83(3)^{\circ}, U=$ $1645(1) \AA^{3}, D_{\mathrm{m}}=1.94(1), Z=4, D_{\mathrm{c}}=2.02 \mathrm{~g} \mathrm{~cm}^{-3} . F(000)=$ 960. Specimen: plate $0.30 \times 0.22 \times 0.07 \mathrm{~mm}, \mu\left(\right.$ Mo- $\left.K_{\alpha}\right)=$ $89 \mathrm{~cm}^{-1}, 2 \theta_{\text {max }}=60^{\circ}, N=4810, N_{\mathrm{o}}=3043, R=0.033$, $R^{\prime}=0.040$.

$\left[\mathrm{AuMe}_{2}(\mathrm{tpm})\right] \mathrm{NO}_{3} \cdot 2 \mathrm{H}_{2} \mathrm{O}$ (2). $\mathrm{C}_{18} \mathrm{H}_{23} \mathrm{AuN}_{4} \mathrm{O}_{5}, M=571.6$, Orthorhombic, space group $P 22_{1} 2_{1}\left(D_{2}^{4}\right.$, no. 19), $a=18.56(1)$, $b=11.150(7), c=9.983(7) \AA, \quad U=2065(2) \AA^{3}, D_{\mathrm{m}}=$ $1.80(1), Z=4, D_{\mathrm{c}}=1.83 \mathrm{~g} \mathrm{~cm}^{-3}, F(000)=1112$. Specimen: plate $0.17 \times 0.16 \times 0.035 \mathrm{~mm}, \mu\left(\mathrm{Mo}-K_{\alpha}\right)=71 \mathrm{~cm}^{-1}$, $2 \theta_{\max .}=50^{\circ}, \quad N=2096, \quad N_{0}=1616, \quad R=0.029, \quad R^{\prime}=$ 0.032 .

$\left[\mathrm{AuMe}_{2}(\mathrm{dpt})\right] \mathrm{NO}_{3}$ (3). $\mathrm{C}_{19} \mathrm{H}_{20} \mathrm{AuN}_{3} \mathrm{O}_{3}, M=534.9$, Monoclinic, space group $P 2_{1} / n\left(C_{2 h}^{5}\right.$, no. 14), $a=14.142(6), b=$ 13.012(7), $c=10.372(3) \AA, \beta=100.60(3)^{\circ}, U=1877(1) \AA^{3}$, $D_{\mathrm{m}}=1.89(1), Z=4, D_{\mathrm{c}}=1.89 \mathrm{~g} \mathrm{~cm}^{-3}, F(000)=1032$. Specimen: prism $0.10 \times 0.10 \times 0.15 \mathrm{~mm}, \mu\left(\mathrm{Mo}_{\mathrm{K}} \mathrm{K}_{\alpha}\right)=78$ 


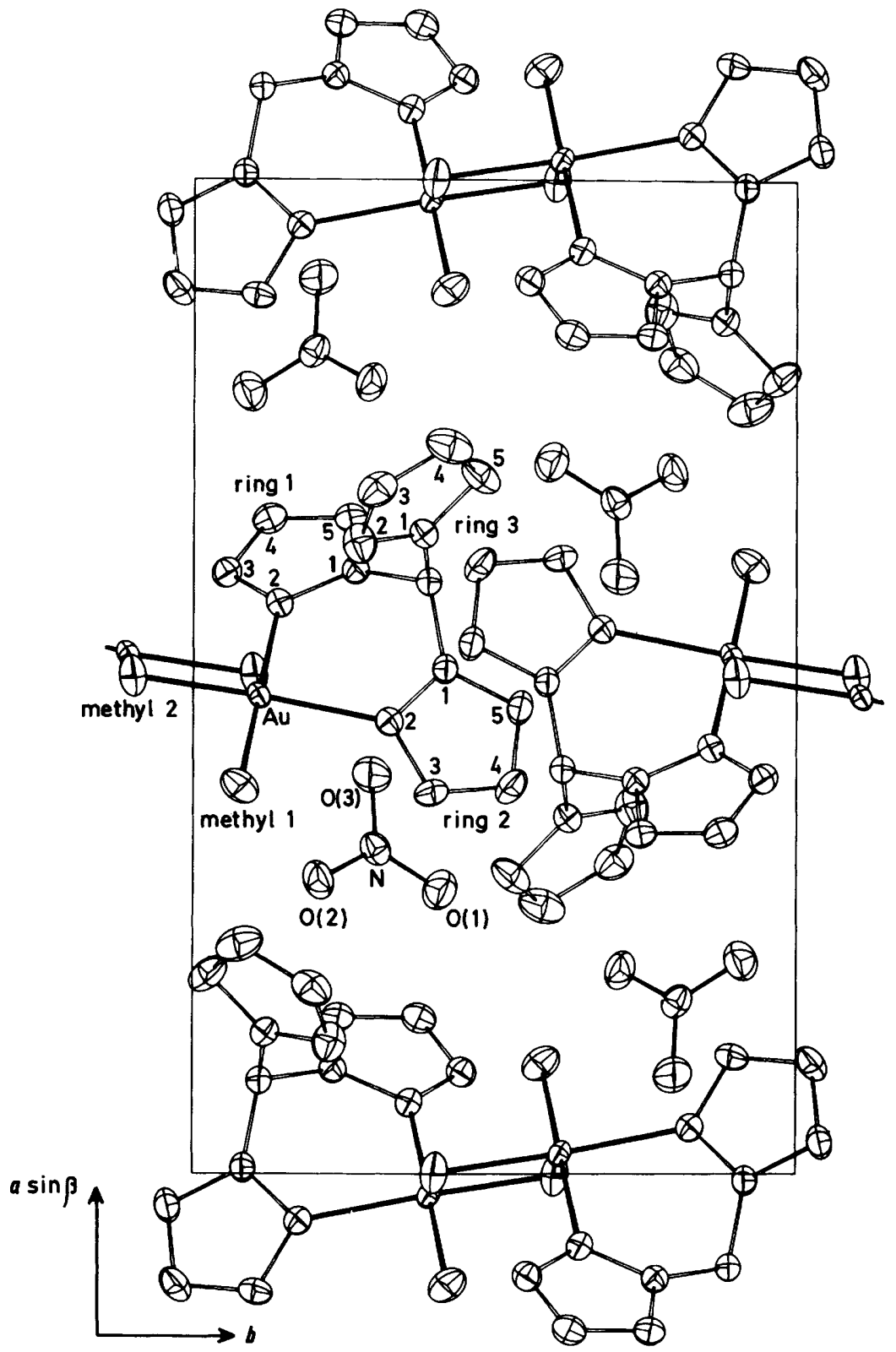

Figure 1. Unit cell contents of $\left[\mathrm{AuMe}_{2}(\mathrm{tpzm})\right] \mathrm{NO}_{3}(1) ; 20 \%$ thermal ellipsoids are shown for the non-hydrogen atoms and bonds in the coordination sphere about $\mathrm{Au}$ are shown as solid

$\mathrm{cm}^{-1}, 2 \theta_{\max .}=50^{\circ}, N=3335, N_{\mathrm{o}}=2529, R=0.042, R^{\prime}=$ 0.050 .

Within each molecule, hydrogen atom labelling follows that of the parent carbon, those for the methyl group being suffixed A,B,C.

\section{Results and Discussion}

Preparation and Characterization of Complexes.-Evaporation to low volume of aqueous solutions containing equimolar quantities of ligand (L) and dimethylgold(III) nitrate, obtained by filtration of precipitated silver iodide from a mixture of dimethylgold(III) iodide and silver nitrate, gave crystals of the required complexes [equations (1) and (2)].

$\frac{1}{2}\left(\mathrm{AuMe}_{2} \mathrm{I}\right)_{2}$ (light petroleum) $+\mathrm{AgNO}_{3}(\mathrm{aq}) \rightarrow$

$$
\mathrm{AgI} \downarrow+\mathrm{AuMe}_{2}\left(\mathrm{NO}_{3}\right)(\mathrm{aq})
$$

$\mathrm{AuMe}_{2}\left(\mathrm{NO}_{3}\right)(\mathrm{aq})+\mathrm{L} \longrightarrow\left[\mathrm{AuMe}_{2} \mathrm{~L}\right] \mathrm{NO}_{3}$
Infrared and Raman spectra indicate the presence of AuMe ligand, and nitrate groups with band positions altered from those of the unco-ordinated species. The Raman spectra have intense bands in the region expected for $\mathrm{v}\left(\mathrm{AuC}_{2}\right)^{8,18}$ and the complexes have molar conductivities in water that are characteristic of $1: 1$ electrolytes (Table 1).

Structures of the Complexes in Methanol.-Proton n.m.r. spectra of cations $[\mathrm{HgMeL}]^{+}$involving polydentate ligands containing pyridyl rings often reveal the mode of co-ordination of the ligands because unco-ordinated rings can adopt conformations resulting in increased shielding of the methyl group from ring-current anisotropy, e.g. for $\mathrm{L}=2$-benzylpyridine a crystal structure determination ${ }^{19}$ has shown the methyl group to be above the plane of the phenyl ring, and the $\mathrm{HgMe}^{1} \mathrm{H}$ resonance ${ }^{20}$ occurs $0.29-0.36$ p.p.m. upfield from unidentate pyridine ${ }^{20}$ and bidentate di-2-pyridylmethane 


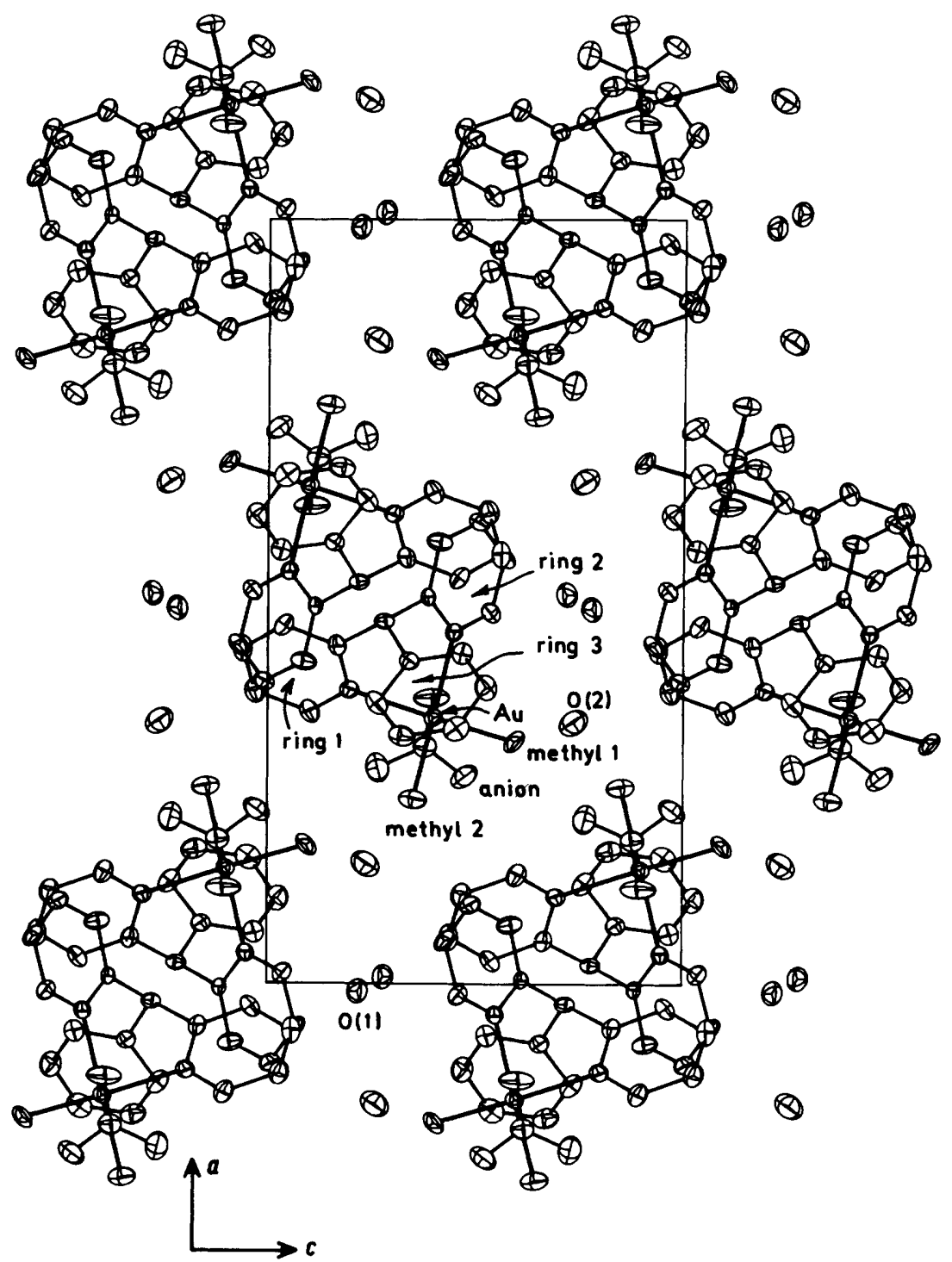

Figure 2. Unit cell contents of $\left[\mathrm{AuMe}_{2}(\mathrm{tpm})\right] \mathrm{NO}_{3}(2)$; see caption to Figure 1

complexes. ${ }^{11}$ For the 2-benzylpyridine complex the orientation of the ring results from the presence of a weak $\mathrm{Hg} \pi$ interaction. ${ }^{19}$<smiles>C[C@@H]1CC[C@@H]2CC[C@@H]1N2</smiles>

I

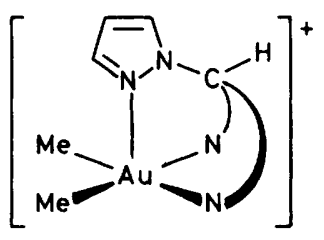

II<smiles></smiles>

III
Similarly, for $\left[\mathrm{AuMe}_{2} \mathrm{~L}\right]^{+}$, the presence of an unco-ordinated ring, e.g. a pyrazolyl ring for $\mathrm{L}=\mathrm{tpzm}$, is expected to result in a chemical shift for the $\mathrm{AuMe}_{2}$ protons upfield from that for the dpzm complex if conformation I is adopted, but similar to the dpzm complex if conformations II or III are adopted.

In the tpzm complex the $\mathrm{AuMe}_{2}{ }^{1} \mathrm{H}$ resonance has a chemical shift similar to those of the complexes of the bidentate ligands dpm and dpzm (1.34-1.46 p.p.m.) (Table 1), indicating conformation II or III for this complex. However, complexes involving $\mathrm{dpt}, \mathrm{tpm}$, and tpmo have the proton resonance $0.43-0.59$ p.p.m. upfield from its position for the dpzm complexes, indicating conformation $I$, and consistent with tpm and tpmo being present as bidentate ligands with conformation I while tpzm is present as either tridentate (II) or bidentate (III).

Structures in the Solid State.-Aspects of the molecular geometry of complexes formed by tpzm, tpm, and dpt are given in Tables $2-6$, and views of the cations $\left[\mathrm{AuMe}_{2} \mathrm{~L}\right]^{+}$are given in Figures $4-6$.

The nitrate ions are regular (within $3 \sigma$ in bond lengths and angles), planar, and are not co-ordinated to gold as oxygen 
Table 2. Fractional atomic co-ordinates of complexes (1)-(3) with estimated standard deviations in parentheses

\begin{tabular}{|c|c|c|c|c|c|c|c|c|c|}
\hline \multirow[b]{2}{*}{ Atom } & \multicolumn{3}{|c|}{$\left[\mathrm{AuMe}_{2}(\mathrm{tpzm})\right] \mathrm{NO}_{3}(1)$} & \multicolumn{3}{|c|}{$\left[\mathrm{AuMe}_{2}(\mathrm{tpm})\right] \mathrm{NO}_{3} \cdot 2 \mathrm{H}_{2} \mathrm{O}(2)$} & \multicolumn{3}{|c|}{ 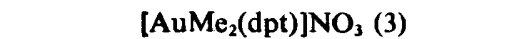 } \\
\hline & $x$ & $y$ & $z$ & $x$ & \multicolumn{4}{|c|}{ (i) Cation } & $z$ \\
\hline $\mathrm{Au}$ & $0.47936(1)$ & $0.10838(2)$ & $0.21070(2)$ & $0.34871(2)$ & $0.38077(4)$ & $0.39974(5)$ & $0.28852(3)$ & $0.26626(3)$ & $0.10644(3)$ \\
\hline \multicolumn{10}{|c|}{ methyl group 1} \\
\hline $\mathrm{C}$ & $0.3882(5)$ & $0.0762(9)$ & $0.0387(8)$ & $0.3177(7)$ & $0.3805(14)$ & $0.5945(13)$ & $0.1690(8)$ & $0.3253(9)$ & $0.1631(12)$ \\
\hline $\mathrm{H}(\mathrm{A})$ & $0.390(-)$ & $-0.010(-)$ & $-0.010(-)$ & $0.360(-)$ & $0.413(-)$ & $0.657(-)$ & $0.120(-)$ & $0.273(-)$ & $0.197(-)$ \\
\hline$H(B)$ & $0.335(-)$ & $0.078(-)$ & $0.054(-)$ & $0.279(-)$ & $0.438(-)$ & $0.608(--)$ & $0.200(-)$ & $0.378(-)$ & $0.224(-)$ \\
\hline $\mathrm{H}(\mathrm{C})$ & $0.390(-)$ & $0.152(-)$ & $-0.020(-)$ & $0.305(-)$ & $0.306(-)$ & $0.625(--)$ & $0.140(-)$ & $0.390(-)$ & $0.130-)$ \\
\hline \multicolumn{10}{|c|}{ methyl group 2} \\
\hline $\mathrm{C}$ & $0.4992(6)$ & $-0.0992(8)$ & $0.2168(9)$ & $0.2421(6)$ & $0.3903(13)$ & $0.3507(15)$ & $0.2171(9)$ & $0.1293(9)$ & $0.0829(11)$ \\
\hline $\mathrm{H}(\mathrm{A})$ & $0.480(-)$ & $-0.140(-)$ & $0.290(-)$ & $0.220(-)$ & $0.440(-)$ & $0.437(-)$ & $0.260(-)$ & $0.084(-)$ & $0.138(--)$ \\
\hline $\mathrm{H}(\mathrm{B})$ & $0.465(-)$ & $-0.141(-)$ & $0.133(-)$ & $0.234(-)$ & $0.432(-)$ & $0.269(-)$ & $0.250(-)$ & $0.093(-)$ & $0.025(-)$ \\
\hline$H(C)$ & $0.556(-)$ & $-0.120(-)$ & $0.226(-)$ & $0.220(-)$ & $0.312(-)$ & $0.345(-)$ & $0.171(-)$ & $0.139(-)$ & $0.133(-)$ \\
\hline \multicolumn{10}{|c|}{ (ii) Ligand } \\
\hline C & $0.5942(4)$ & $0.3887(6)$ & $0.3538(6)$ & $0.4743(5)$ & $0.5303(9)$ & $0.2805(12)$ & $0.5026(6)$ & $0.3087(8)$ & $0.2377(8)$ \\
\hline $\mathbf{H}$ & $0.618(-)$ & $0.469(-)$ & $0.406(-)$ & $0.513(-)$ & $0.583(-)$ & $0.244(-)$ & $0.568(-)$ & $0.319(-)$ & $0.281(-)$ \\
\hline \multicolumn{10}{|c|}{ base: ring 1} \\
\hline$C, N(1)$ & $0.6051(3)$ & $0.2670(5)$ & $0.4385(5)$ & $0.4426(7)$ & $0.4564(10)$ & $0.1670(13)$ & $0.5023(7)$ & $0.2349(7)$ & $0.1255(9)$ \\
\hline$N(2)$ & $0.5718(3)$ & $0.1426(5)$ & $0.3970(6)$ & $0.3849(4)$ & $0.3863(9)$ & $0.1967(10)$ & $0.4172(6)$ & $0.2066(6)$ & $0.0532(7)$ \\
\hline$C(3)$ & $0.6023(4)$ & $0.0543(7)$ & $0.4976(7)$ & $0.3562(7)$ & $0.3152(10)$ & $0.1016(14)$ & $0.4147(8)$ & $0.1475(8)$ & $-0.0551(9)$ \\
\hline$H(3)$ & $0.589(-)$ & $-0.042(-)$ & $0.499(-)$ & $0.318(-)$ & $0.262(-)$ & $0.127(-)$ & $0.352(-)$ & $0.130(-)$ & $-0.111(-)$ \\
\hline $\mathrm{C}(4)$ & $0.6567(4)$ & $0.1266(7)$ & $0.6020(7)$ & $0.3823(8)$ & $0.3133(12)$ & $-0.0317(15)$ & $0.4974(11)$ & $0.1119(8)$ & $-0.0911(11)$ \\
\hline $\mathrm{H}(4)$ & $0.688(-)$ & $0.091(-)$ & $0.687(-)$ & $0.364(-)$ & $0.262(-)$ & $-0.099(-)$ & $0.494(-)$ & $0.068(-)$ & $-0.168(-)$ \\
\hline$C(5)$ & $0.6580(4)$ & $0.2593(7)$ & $0.5612(6)$ & $0.4380(8)$ & $0.3902(14)$ & $-0.0607(13)$ & $0.5848(9)$ & $0.1357(9)$ & $-0.0159(11)$ \\
\hline$H(5)$ & $0.691(-)$ & $0.377(-)$ & $0.611(-)$ & $0.458(-)$ & $0.396(-)$ & $-0.152(-)$ & $0.644(-)$ & $0.107(-)$ & $-0.037(-)$ \\
\hline$C(6)$ & & & & $0.4689(7)$ & $0.4601(12)$ & $0.0389(14)$ & $0.5881(8)$ & $0.1986(8)$ & $0.0920(10)$ \\
\hline \multirow[t]{2}{*}{ H(6) } & & & & $0.510(-)$ & $0.513(-)$ & $0.020(-)$ & $0.650(-)$ & $0.217(-)$ & $0.145(-)$ \\
\hline & ring 2 & & & & & & & & \\
\hline$C, N(1)$ & $0.5062(3)$ & $0.4163(5)$ & $0.2884(5)$ & $0.5062(5)$ & $0.4473(9)$ & $0.3859(12)$ & $0.4587(6)$ & $0.4098(7)$ & $0.1872(8)$ \\
\hline$N(2)$ & $0.4534(3)$ & $0.3243(8)$ & $0.2089(5)$ & $0.4602(4)$ & $0.3742(9)$ & $0.4486(8)$ & $0.3650(5)$ & $0.4090(6)$ & $0.1302(7)$ \\
\hline$C(3)$ & $0.3822(4)$ & $0.3943(8)$ & $0.1572(7)$ & $0.4857(7)$ & $0.2956(11)$ & $0.5374(13)$ & $0.3219(7)$ & $0.4976(8)$ & $0.0839(8)$ \\
\hline$H(3)$ & $0.333(-)$ & $0.353(-)$ & $0.097(-)$ & $0.452(-)$ & $0.240(-)$ & $0.584(-)$ & $0.252(-)$ & $0.497(-)$ & $0.045(-)$ \\
\hline$C(4)$ & $0.3892(4)$ & $0.5267(8)$ & $0.2009(7)$ & $0.5575(7)$ & $0.2908(13)$ & $0.5703(13)$ & $0.3714(8)$ & $0.5895(8)$ & $0.0944(9)$ \\
\hline$H(4)$ & $0.348(-)$ & $0.602(-)$ & $0.181(-)$ & $0.573(-)$ & $0.233(-)$ & $0.640(-)$ & $0.337(-)$ & $0.654(-)$ & $0.064(-)$ \\
\hline$C(5)$ & $0.4680(4)$ & $0.5399(7)$ & $0.2839(7)$ & $0.6045(6)$ & $0.3691(14)$ & $0.5089(13)$ & $0.4670(9)$ & $0.5910(9)$ & $0.1498(9)$ \\
\hline$H(5)$ & $0.493(-)$ & $0.621(-)$ & $0.328(-)$ & $0.655(-)$ & $0.367(-)$ & $0.532(-)$ & $0.503(-)$ & $0.656(-)$ & $0.155(-)$ \\
\hline$C(6)$ & & & & $0.5783(6)$ & $0.4465(11)$ & $0.4136(17)$ & $0.5113(7)$ & $0.4986(8)$ & $0.1972(9)$ \\
\hline \multirow[t]{2}{*}{$H(6)$} & & & & $0.610(-)$ & $0.501(-)$ & $0.369(-)$ & $0.581(-)$ & $0.496(-)$ & $0.237(-)$ \\
\hline & ring 3 & & & & & & & & \\
\hline$C, N(1)$ & $0.6428(3)$ & $0.3797(5)$ & $0.2639(5)$ & $0.4225(6)$ & $0.6208(13)$ & $0.3405(12)$ & $0.4555(7)$ & $0.2658(7)$ & $0.3485(9)$ \\
\hline$N, C(2)$ & $0.6328(4)$ & $0.2746(6)$ & $0.1770(6)$ & $0.4326(6)$ & $0.6489(9)$ & $0.4686(11)$ & $0.4148(8)$ & 0.333 & $0.4290(9)$ \\
\hline $\mathrm{H}(2)$ & & & & & & & $0.415(-)$ & $0.410(-)$ & $0.412(-)$ \\
\hline$C(3)$ & $0.6865(5)$ & $0.3034(10)$ & $0.1110(8)$ & $0.3881(9)$ & $0.7302(14)$ & $0.5258(16)$ & $0.3764(8)$ & $0.2943(10)$ & $0.5329(10)$ \\
\hline$H(3)$ & $0.692(-)$ & $0.248(-)$ & $0.037(-)$ & $0.400(-)$ & $0.750(-)$ & $0.691(-)$ & $0.348(-)$ & $0.342(-)$ & $0.589(-)$ \\
\hline C(4) & $0.7303(6)$ & $0.4234(12)$ & $0.1573(10)$ & $0.3345(9)$ & $0.7850(13)$ & $0.4551(18)$ & $0.3751(7)$ & $0.1899(11)$ & $0.5549(10)$ \\
\hline $\mathrm{H}(4)$ & $0.732(-)$ & $0.425(-)$ & $0.156(-)$ & $0.304(-)$ & $0.840(-)$ & $0.499(-)$ & $0.347(-)$ & $0.163(-)$ & $0.625(-)$ \\
\hline$C(5)$ & $0.7008(5)$ & $0.4734(9)$ & $0.2553(8)$ & $0.3248(7)$ & $0.7588(13)$ & $0.3233(19)$ & $0.4141(7)$ & $0.1239(9)$ & $0.4798(10)$ \\
\hline$H(5)$ & $0.717(-)$ & $0.557(-)$ & $0.307(-)$ & $0.290(-)$ & $0.803(-)$ & $0.268(-)$ & $0.414(-)$ & $0.051(-)$ & $0.499(-)$ \\
\hline$C(6)$ & & & & $0.3676(7)$ & $0.6715(11)$ & $0.2628(13)$ & $0.4546(7)$ & $0.1600(8)$ & $0.3737(9)$ \\
\hline$H(6)$ & & & & $0.361(-)$ & $0.645(-)$ & $0.171(-)$ & $0.480(-)$ & $0.112(-)$ & $0.321(-)$ \\
\hline \multicolumn{10}{|c|}{ (iii) Anion } \\
\hline $\mathbf{N}$ & $0.3264(4)$ & $0.3021(6)$ & $0.4245(5)$ & $0.3108(7)$ & $0.0858(9)$ & $0.3801(14)$ & $0.7321(7)$ & $0.0603(10)$ & $0.2869(9)$ \\
\hline$O(1)$ & $0.2853(4)$ & $0.4073(6)$ & $0.4324(6)$ & $0.3744(5)$ & $0.1091(10)$ & $0.3951(15)$ & $0.7844(7)$ & $0.1363(7)$ & $0.3095(8)$ \\
\hline$O(2)$ & $0.2952(3)$ & $0.2066(5)$ & $0.3506(5)$ & $0.2720(6)$ & $0.0636(11)$ & $0.4747(12)$ & $0.6576(6)$ & $0.0543(9)$ & $0.3305(9)$ \\
\hline$O(3)$ & $0.4007(4)$ & $0.2958(6)$ & $0.4918(6)$ & $0.2832(7)$ & $0.0862(11)$ & $0.2652(12)$ & $0.7554(7)$ & $-0.0095(9)$ & $0.2213(12)$ \\
\hline \multicolumn{10}{|c|}{ (iv) Solvent } \\
\hline$O(1)$ & & & & $-0.0095(5)$ & $0.4199(9)$ & 0.2 & & & \\
\hline$O(2)$ & & & & $0.3424(7)$ & $0.0636(12)$ & $0.7373(13)$ & & & \\
\hline
\end{tabular}




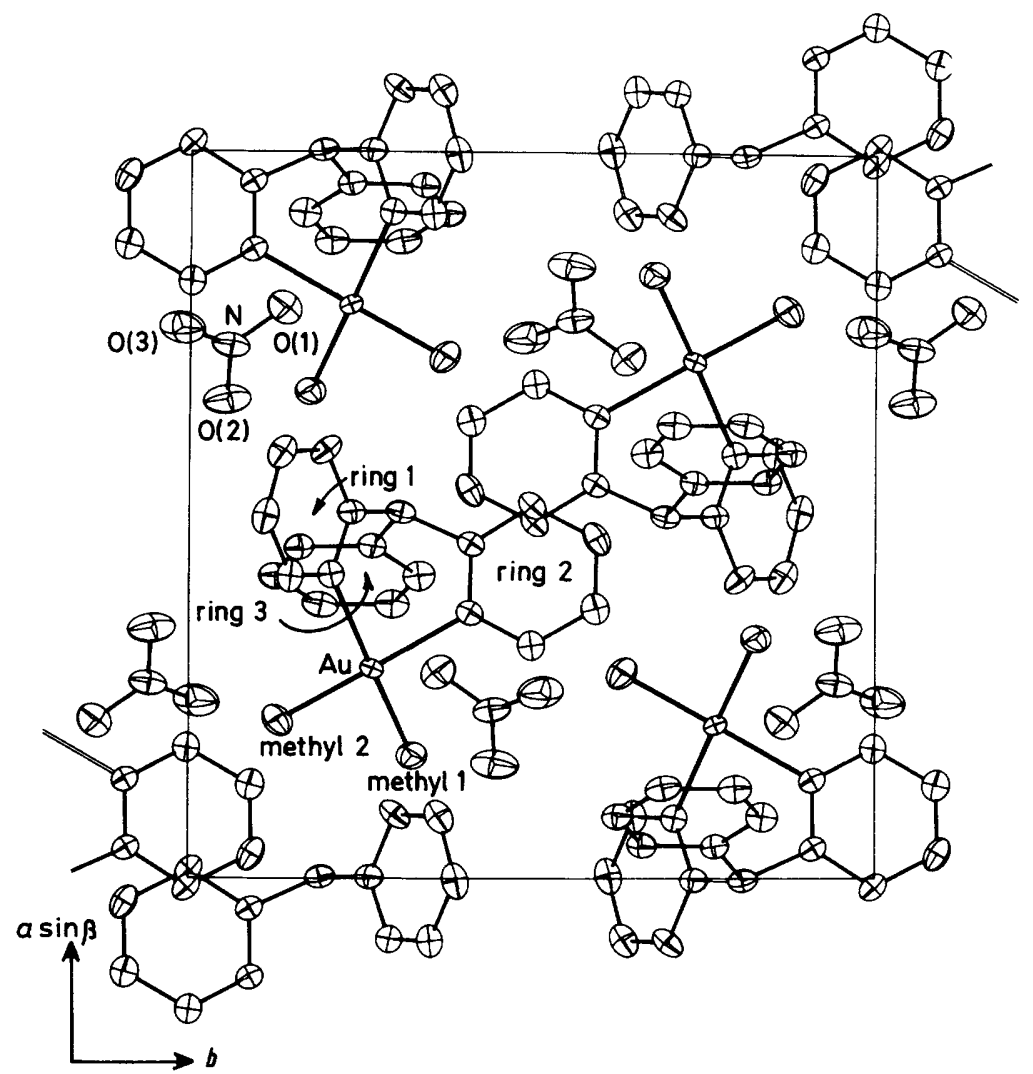

Figure 3. Unit cell contents of $\left[\mathrm{AuMe}_{2}(\mathrm{dpt})\right] \mathrm{NO}_{3}$ (3); see caption to Figure 1

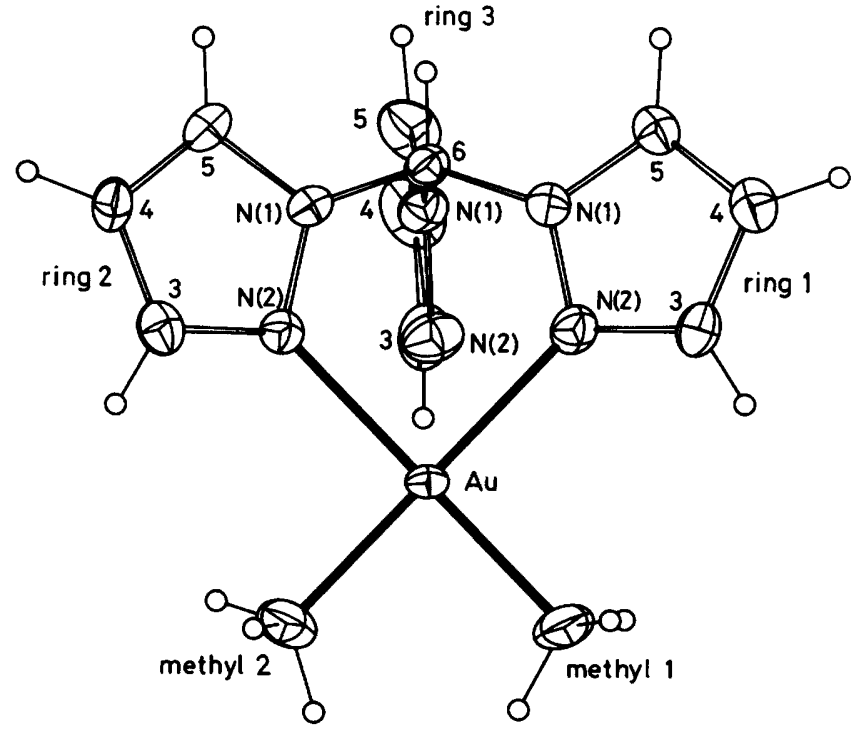

Figure 4. Projection of $\left[\mathrm{AuMe}_{2}(\mathrm{tpzm})\right]^{+}$

atoms are at least $3.75 \AA$ from gold, except for one contact of 3.067(10) $\AA$ in the tpm complex.

The pyrazolyl, pyridyl, and phenyl rings are planar in all the complexes, with all ring atoms within $0.02 \AA$ of their mean planes. In all three complexes the gold atom has essentially square-planar geometry with the ligands present as bidentate cis- $\mathrm{AuC}_{2} \mathrm{~N}_{2}$, with angles $\mathrm{C}-\mathrm{Au}-\mathrm{C} 86.9(5)-87.4(6)^{\circ}, \mathrm{C}-\mathrm{Au}-\mathrm{N}$ $92.7(3)-94.5(4)^{\circ}$, and $\mathrm{N}-\mathrm{Au}-\mathrm{N} 84.8(3)-86.8(2)^{\circ}$. The gold

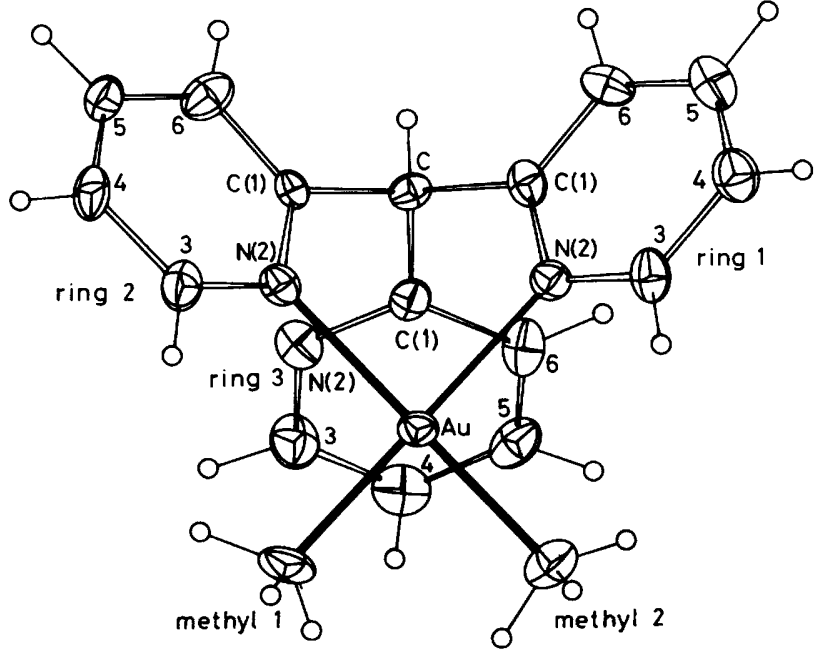

Figure 5. Projection of $\left[\mathrm{AuMe}_{2}(\mathrm{tpm})\right]^{+}$

atom is $0.02-0.34 \AA$ from the mean planes of the co-ordinated pyrazolyl and pyridyl rings, and is $0.33 \AA$ from the mean plane of the axial pyrazolyl ring. The planes of the coordinated rings form dihedral angles of $22.2^{\circ}, 24.4^{\circ}(\mathrm{tpzm})$ and $43.0-46.2^{\circ}$ (dpt and tpm) with the mean plane of the cis$\mathrm{AuC}_{2} \mathrm{~N}_{2}$ group. Earlier structural determinations of $\mathrm{AuR}_{2}$ complexes are of low accuracy, ${ }^{21-23}$ but the most recent example, $\left[\mathrm{AuMe}_{2}(\mathrm{OH})\right]_{4}$, has eight crystallographically independent $\mathrm{Au}-\mathrm{C}$ bond lengths with a mean of $2.05 \pm 0.08$ 


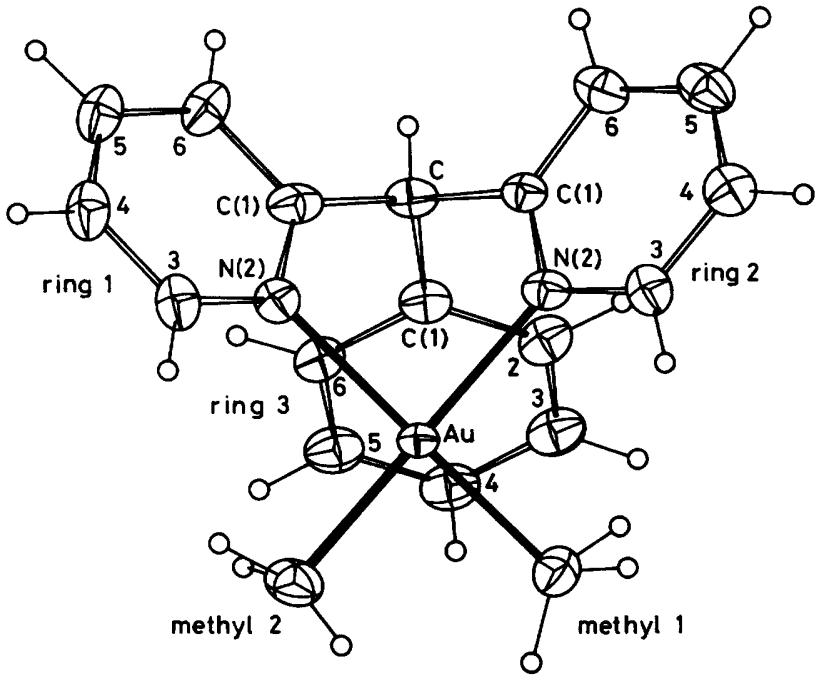

Figure 6. Projection of $\left[\mathrm{AuMe}_{2}(\mathrm{dpt})\right]^{+}$

Table 3. Gold atom environment in the cations $\left[\mathrm{AuMe}_{2} \mathrm{~L}\right]^{+}$; atoms derived from the methyl groups are italicized

$\begin{array}{lccc}\quad \text { L } & \text { tpzm } & \text { tpm } & \text { dpt } \\ \quad(i) \text { Distances }(\AA) & & & \\ \mathrm{Au}-C(I) & 2.023(7) & 2.028(13) & 2.039(12) \\ \mathrm{Au}-C(2) & 2.031(8) & 2.041(12) & 2.040(11) \\ \mathrm{Au}-\mathrm{N}(12) & 2.141(5) & 2.136(10) & 2.142(8) \\ \mathrm{Au}-\mathrm{N}(22) & 2.129(5) & 2.127(8) & 2.141(8) \\ \quad(i i) \text { Angles }\left(^{\circ}\right) & & & \\ C(I)-\mathrm{Au}-C(2) & 87.0(3) & 87.4(6) & 86.9(5) \\ C(I)-\mathrm{Au}-\mathrm{N}(12) & 177.5(11) & 177.6(6) & 177.9(6) \\ C(1)-\mathrm{Au}-\mathrm{N}(22) & 92.7(3) & 93.2(4) & 93.9(4) \\ C(2)-\mathrm{Au}-\mathrm{N}(12) & 93.3(3) & 94.3(5) & 94.5(4) \\ C(2)-\mathrm{Au}-\mathrm{N}(22) & 176.9(5) & 178.8(7) & 179.2(12) \\ \mathrm{N}(12)-\mathrm{Au}-\mathrm{N}(22) & 86.8(2) & 85.0(3) & 84.8(3)\end{array}$

Table 5. Anion geometries in the complexes
(1)
(2)

(3)

(i) Distances $(\AA)$

$\mathrm{N}-\mathrm{O}(1)$

$\mathrm{N}-\mathrm{O}(3)$

$1.244(9)$

$1.22(2) \quad 1.23(1)$

$1.223(7) \quad 1.21(2) \quad 1.22(1)$

(ii) Angles $\left({ }^{\circ}\right)$

$\mathrm{O}(1)-\mathrm{N}-\mathrm{O}(2)$

$\mathrm{O}(1)-\mathrm{N}-\mathrm{O}(3)$

$\mathrm{O}(2)-\mathrm{N}-\mathrm{O}(3)$

$121.7(6)$
$118.6(6)$

$1.26(2)$

$1.22(2)$

$118.6(6)$

121(1)

$120(1)$

121(1)

$118(1) \quad 120(1)$

Table 6. Gold environment planes in the cations $\left[\mathrm{AuMe}_{2} \mathrm{~L}\right]^{+}$of the complexes * (1)-(3)

\begin{tabular}{lrrr} 
& $(1)$ & $(2)$ & \multicolumn{1}{c}{$(3)$} \\
$10^{4} p$ & 8668 & 374 & 1912 \\
$10^{4} p$ & 1478 & 9989 & -2315 \\
$10^{4} r$ & -4763 & 279 & 9539 \\
$s$ & 5.441 & 4.613 & 0.986 \\
$\sigma$ & 0.023 & 0.012 & 0.016 \\
$\mathrm{Au}$ & 0.040 & -0.019 & -0.011 \\
$C(1)$ & -0.004 & 0.011 & 0.018 \\
$C(2)$ & -0.016 & -0.001 & -0.012 \\
$\mathrm{~N}(12)$ & -0.004 & 0.010 & 0.017 \\
$\mathrm{~N}(22)$ & -0.015 & -0.001 & -0.012 \\
$\mathrm{C}$ & 1.003 & 1.700 & 1.668 \\
$\mathrm{C}, \mathrm{N}(11)$ & 0.336 & 0.824 & 0.839 \\
$\mathrm{C}(3)$ & -0.463 & -0.827 & -0.825 \\
$\mathrm{C}, \mathrm{N}(21)$ & 0.269 & 0.827 & 0.772 \\
$\mathrm{C}(23)$ & -0.548 & -0.835 & -0.829 \\
$\mathrm{~N}(32)$ & 2.759 & 3.045 &
\end{tabular}

* Least-squares planes are calculated through $\mathrm{Au}$ and its four nearest neighbours, and given in the form $p X+q Y+r Z=s$, where the right hand orthogonal $\AA$ frame $(X, Y, Z)$ has $X$ parallel to $a, Z$ in the $a c$ plane; $\sigma=$ standard deviation $(\AA)$ of defining atoms $\mathrm{Au}, C(l), C(2), \mathrm{N}(12)$, and $\mathrm{N}(22)$; atom deviations are in $\AA$; methyl $\mathrm{C}$ atoms are italicized.

Table 4. Ligand non-hydrogen geometries with estimated standard deviations in parentheses

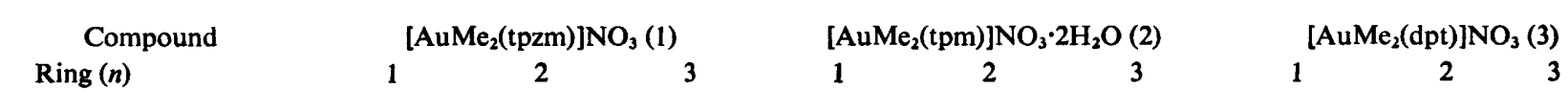

\section{(i) Distances $(\AA)$}

C-C,N(n1)

$\mathrm{C}, \mathrm{N}(n 1)-\mathrm{N}(n 2)$

$\mathrm{C}, \mathrm{N}(n 1)-\mathrm{C}(n 5,6)$

$\mathrm{N}(n 2)-\mathrm{C}(n 3)$

$\mathrm{C}(n 3)-\mathrm{C}(n 4)$

$\mathrm{C}(n 4)-\mathrm{C}(n 5)$

C(n5)-C(n6)

(ii) Angles $\left(^{\circ}\right)$

$\mathrm{Au}-\mathrm{N}(n 2)-\mathrm{C}, \mathrm{N}(n 1)$
$\mathrm{Au}-\mathrm{N}(n 2)-\mathrm{C}(n 3)$
$\mathrm{C}, \mathrm{N}(n 1)-\mathrm{C}, \mathrm{N}(n 2)-\mathrm{C}(n 3)$
$\mathrm{C}, \mathrm{N}(n 1)-\mathrm{C}-\mathrm{C}, \mathrm{N}(n+1,1)$
$\mathrm{C}-\mathrm{C}, \mathrm{N}(n 1)-\mathrm{N}(n 2)$
$\mathrm{C}-\mathrm{C}, \mathrm{N}(n 1)-\mathrm{C}(n 5,6)$
$\mathrm{N}(n 2)-\mathrm{C}, \mathrm{N}(n 1)-\mathrm{C}(n 5,6)$
$\mathrm{N}(n 2)-\mathrm{C}(n 3)-\mathrm{C}(n 4)$
$\mathrm{C}(n 3)-\mathrm{C}(n 4)-\mathrm{C}(n 5)$
$\mathrm{C}(n 4)-\mathrm{C}(n 5)-\mathrm{N}, \mathrm{C}(n 1,6)$
$\mathrm{C}(n 5)-\mathrm{C}(n 6)-\mathrm{C}, \mathrm{N}(n 1)$

$\begin{array}{lll}1.462(8) & 1.447(7) & 1.44 \\ 1.342(7) & 1.355(7) & 1.35 \\ 1.342(7) & 1.348(8) & 1.35 \\ 1.346(8) & 1.333(8) & 1.33 \\ 1.392(9) & 1.355(11) & 1.38 \\ 1.357(10) & 1.350(9) & 1.37\end{array}$

$\begin{array}{lll}1.440(9) & 1.52(2) & 1.52(2) \\ 1.352(8) & 1.36(2) & 1.34(1) \\ 1.350(10) & 1.37(2) & 1.37(2) \\ 1.330(13) & 1.35(2) & 1.33(2) \\ 1.380(14) & 1.42(2) & 1.37(2) \\ 1.376(15) & 1.37(2) & 1.38(2) \\ & 1.39(2) & 1.37(2)\end{array}$

\section{$1.52(2)$}

$1.33(2)$

$1.40(2)$

$1.35(2)$

$1.36(2)$

$1.36(3)$

1.39(2)

$1.51(1)$
$1.35(1)$
$1.41(2)$
$1.35(1)$
$1.37(1)$
$1.37(2)$
$1.38(2)$

$1.51(1)$

$1.35(1)$

$1.37(1)$

$1.35(1)$

$1.38(2)$

$1.37(2)$

$1.40(2)$

1.54(1)

1.41(1)

$1.40(1)$

$1.39(2)$

$1.38(2)$

$1.34(2)$

$1.41(2)$

$\begin{array}{ll}123.7(4) & 123.1(3) \\ 129.5(4) & 131.0(4) \\ 106.6(5) & 104.7(5) \\ 111.3(5) & 112.8(5) \\ 123.7(5) & 123.6(5) \\ 124.8(5) & 125.5(5) \\ 110.9(5) & 110.5(4) \\ 108.5(6) & 111.4(5) \\ 106.7(5) & 106.3(6) \\ 107.2(5) & 107.2(6)\end{array}$

$118.1(8)$

$118.1(8) \quad 119.5(7)$

$121.9(8) \quad 121.4(8)$

104.3(6)

$112.1(5)$

121.9(5)

$124.7(6)$

$113.4(7)$

$110.8(9)$

107.1(9)

$119.8(10)$
$109.7(9)$

$109.7(9)$

117(1)

123(1)

120(1)

$122(1)$

116(1)

121(1)

$119.1(9)$
$112.2(10)$

$117(1)$

$122(1)$

122(1)

122(1)

119(1)

119(1)

119(1)

$\begin{array}{lll} & 118.1(6) & 119.5(6) \\ & 121.7(7) & 120.9(6) \\ 118.5(12) & 120.0(9) & 119.6(8) \\ 114.2(9) & 110.2(7) & 111.7(8) \\ 117(1) & 118.7(9) & 117.1(8) \\ 121(1) & 121.7(8) & 121.8(8) \\ 123(1) & 119.6(9) & 121.1(8) \\ 122(1) & 121.5(9) & 121.4(9) \\ 120(1) & 119.6(10) & 119.5(10) \\ 120(1) & 119.3(12) & 118.6(10) \\ 117(1) & 119.9(9) & 119.7(9)\end{array}$

$119.3(11)$

$113.9(8)$

$119.7(9)$

121.1(9)

119.1(9)

120.6(11)

$121.0(11)$

$120.5(11)$

$119.5(10)$ 
$\AA$ (average deviation from the mean), ${ }^{23}$ similar to that for the present complexes, 2.023(7)-2.041(12) $\AA$. The $\mathrm{Au}^{-\mathrm{N}}$ distances, $2.127(8)-2.142(8) \AA$, are similar to those noted for five-co-ordinate $\mathrm{Au}^{111}$ in $\left[\mathrm{AuX}_{3}(\mathrm{dmphen})\right]$ (dmphen $=2,9$ dimethyl-1,10-phenanthroline, $\mathrm{X}=\mathrm{Cl}$ or $\mathrm{Br})^{*}$ which have $\mathrm{Au}-\mathrm{N} 2.09$ (1) $(\mathrm{Cl})$ and $2.08(2) \AA(\mathrm{Br}),{ }^{24}$ for the nitrogen atom co-ordinated as part of the square plane $\mathrm{AuX}_{3} \mathrm{~N}$.

In addition to functioning as bidentate ligands to give square-planar geometry for gold the ligands adopt conformation II (tpzm complex, with the mean plane of the axial pyrazolyl ring forming a dihedral angle of $86.6^{\circ}$ with the $\mathrm{AuC}_{2} \mathrm{~N}_{2}$ mean plane) or I (tpm and dpt complexes), but not III. There is no definite evidence of $\mathrm{Au} \pi$ interactions in the tpm and dpt complexes since, apart from $C(31)$ which is apparently constrained by the ligand geometry to be close to gold in conformation I [3.064(12) $\AA(\mathrm{tpm}), 3.114(8) \AA(\mathrm{dpt})]$, the carbon and nitrogen atoms of the rings are all $>3.44 \AA$ from the gold atom.

Although the axial $\mathrm{Au} \cdots \mathrm{N}$ distance in the tpzm complex is long, 3.139(7) $\AA$, the presence of a weak interaction is indicated since the gold atom lies $0.040 \AA$ above the mean plane of the cis-AuC $\mathrm{N}_{2}$ unit toward the axial nitrogen, whereas in the tpm and dpt complexes the gold atoms lie slightly below this plane [0.019 and $0.011 \AA$, respectively] (Table 6). The carbon and nitrogen atoms all lie below this plane in the tpzm complex, and the gold atom lies $0.050 \AA$ above the mean plane defined by the carbon and nitrogen atoms.

\section{Discussion}

The crystallographic studies indicate the dominance of squareplanar geometry in the chemistry of $\mathrm{Au}^{\prime \prime \prime} \mathrm{Me}_{2}$, and show the presence of a weak axial $\mathrm{Au} \cdots \mathrm{N}$ interaction in one complex and the flexibility of aromatic tripod ligands to bond as either bidentates or tridentates.

Despite the flexibility of the ligands, conformation III, involving the third potential donor group in an orientation well removed sterically from the gold atom, is not adopted in the complexes. The structures deduced for methanol solutions of the complexes from ${ }^{1} \mathrm{H}$ n.m.r. spectra, i.e. the presence of $\mathrm{dpt}$ and tpm in conformation I and tpzm in conformation II or III, are consistent with the solid-state configurations determined here.

The different behaviour of $\mathrm{AuMe}_{2}$ toward tpzm and tpm may result from several factors. These include $(i)$ the ligand geometry of tpzm compared with tpm and the preference for a dominant square-planar geometry with, at most, weak axial interactions (rotation of the axial pyridyl ring to allow coordination would result in a much shorter $\mathrm{Au} \cdots \mathrm{N}$ distance than in the tpzm complex), (ii) low basicity of tpzm compared with tpm, $\dagger$ and (iii) expected differences in ' softness,' and $\sigma$ and $\pi$-bonding characteristics of pyrazolyl and pyridyl rings. ${ }^{26}$

* However, reaction of $\left(\mathrm{AuEt}_{2} \mathrm{Br}\right)_{2}$ with 1,10-phenanthroline (phen), ${ }^{7}$ and both $\left(\mathrm{AuMe} \mathrm{Cl}_{2} \mathrm{Cl}_{2}{ }^{6}\right.$ and $\left(\mathrm{AuEt}_{2} \mathrm{Br}\right)_{2}{ }^{7}$ with bipy give ionic complexes $\left[\mathrm{AuR}_{2} \mathrm{~L}\right]\left[\mathrm{AuR}_{2} \mathrm{X}_{2}\right](\mathrm{R}=\mathrm{Me}$ or $\mathrm{Et}, \mathrm{X}=\mathrm{Br}$ or $\mathrm{Cl}$, $\mathbf{L}=$ phen or bipy), rather than five-co-ordinate analogues of $\left[\mathrm{AuX}_{3}(\mathrm{dmphen})\right](\mathrm{X}=\mathrm{Cl}, \mathrm{Br})$.

$\dagger$ The base tpm has $\log K_{\mathrm{H}}$ [p $K_{\mathrm{a}}$ of $\mathrm{Htpm}^{+}$in $50 \%$ dioxan-water] $3.61,11$ but tpzm has $\log K_{\mathrm{H}}<c a .1 .25 .^{25}$

\section{Acknowledgements}

We thank the Australian Research Grants Committee for financial support, C. V. Lee and E. E. George for assistance with ligand synthesis, the University of Tasmania for an honours scholarship (to N. J. M.), and the Education Department of Tasmania for leave of absence (to N. J. M.).

\section{References}

1 See, for example, D. L. Rabenstein, Acc. Chem. Res., 1978, 11, 100.

2 See, for example, B. Armer and H. Schmidbaur, Angew. Chem., Int. Ed. Engl., 1970, 9, 101; R. J. Puddephatt, 'The Chemistry of Gold,' Elsevier, New York, 1978; H. Schmidbaur, 'Gmelin Handbuch der Anorganischen Chemie. Organogold Compounds,' Springer-Verlag, Berlin, 1980.

3 G. C. Stocco, L. Pellerito, and N. Bertazzi, Inorg. Chim. Acta, $1975,12,67$.

4 A. J. Canty, N. Chaichit, B. M. Gatehouse, and E. E. George, Inorg. Chem., 1981, 20, 4293.

5 H. Hagnauer, G. C. Stocco, and R. S. Tobias, J. Organomet. Chem., 1972, 46, 179.

6 H. Schmidbaur and K. C. Dash, J. Am. Chem. Soc., 1973, 95, 4855.

7 M. E. Foss and C. S. Gibson, J. Chem. Soc., 1949, 3063.

8 W. M. Scovell, G. C. Stocco, and R. S. Tobias, Inorg. Chem., $1970,9,2682$.

9 R. S. Tobias, C. E. Rice, W. Beck, B. Purucker, and K. Bartel, Inorg. Chim. Acta, 1979, 35, 11.

10 E. Leete and L. Marion, Can. J. Chem., 1952, 30, 563; A. J. Canty and C. V. Lee, unpublished work.

11 A. J. Canty, N. Chaichit, B. M. Gatehouse, E. E. George, and G. Hayhurst, Inorg. Chem., 1981, 20, 2414.

12 F. H. Brain and C. S. Gibson, J. Chem. Soc., 1931, 762.

13 B. P. Block, Inorg. Synth., 1953, 4, 14.

14 D. T. Cromer and J. B. Mann, Acta Crystallogr., 1968, 24, 321.

15 D. T. Cromer and D. Liberman, J. Chem. Phys., 1970, 53, 1891.

16 R. F. Stewart, E. R. Davidson, and W. T. Simpson, J. Chem. Phys., 1965, 42, 3175.

17 'The X-RAY System, Version of March 1976,' Technical Report TR-446, ed. J. M. Stewart, Computer Science Centre, University of Maryland.

18 M. G. Miles, G. E. Glass, and R. S. Tobias, J. Am. Chem. Soc., 1966, 88, 5738; G. C. Stocco and R. S. Tobias, J. Am. Chem. Soc., 1971, 93, 5057; P. L. Kuch and R. S. Tobias, J. Organomet. Chem., 1976, 122, 429.

19 A. J. Canty, N. Chaichit, and B. M. Gatehouse, Acta Crystallogr., Sect. B, 1980, 36, 786.

20 A. J. Canty and A. Marker, Inorg. Chem., 1976, 15, 425.

21 A. Burawoy, C. S. Gibson, G. C. Hampson, and H. M. Powell, J. Chem. Soc., 1937, 1690.

22 R. F. Phillips and H. M. Powell, Proc. R. Soc. London, Ser. A., 1939, 173, 147.

23 G. E. Glass, J. H. Konnert, M. G. Miles, D. Britton, and R. S. Tobias, J. Am. Chem. Soc., 1968, 90, 1131.

24 W. T. Robinson and E. Sinn, J. Chem. Soc., Dalton Trans., 1975, 726.

25 A. J. Canty and C. V. Lee, unpublished work.

2.6 See, for example, A. J. Canty and C. V. Lee, Inorg. Chim. Acta, $1981,54, \mathrm{~L} 205$. 